\title{
The construction of the disaster and the "privatization" of mining regulation: reflections on the tragedy of the Rio Doce Basin, Brazil
}

\section{Rodrigo Salles Pereira dos Santos}

Instituto de Filosofia e Ciências Sociais, Programa de Pós-graduação em Sociologia e Antropologia, Departamento de Sociologia, Universidade Federal do Rio de Janeiro - UFRJ, Rio de Janeiro, RJ, Brasil

\section{Bruno Milanez}

Faculdade de Engenharia, Programa de Pós-graduação em Geografia, Departamento de Engenharia de Produção e Mecânica, Universidade Federal de Juiz de Fora - UFJF, Juiz de Fora, MG, Brasil

\begin{abstract}
In this paper, we present an interpretation of the Samarco/Vale/BHP Billiton disaster, which highlights the relations between State, market and civil society and the rearrangement of environmental regulation of the mining industry in Brazil. We discuss the mutually constitutive changes in the roles of the State and of private companies, with emphasis on environmental and social dimensions, revealing the selective exclusion of civil society from the process. Based on document analysis and direct observation, we analyze regulatory forms related to environmental licensing and monitoring of Samarco's operations, as well as management of impacts of the disaster in the Rio Doce basin, with the establishment of the Renova Foundation. Results are consistent with the hypothesis of a mix of weak and private regulatory standards (self-regulation), integrating 'negative' and 'positive' dimensions, which add corporate forms of private and public regulation to the process of institutional dismantlement.
\end{abstract}

Key words: mining; regulation; state-market relations; disaster; Samarco. 


\section{A construção do desastre e a "privatização" da regulação mineral:}

reflexões sobre a tragédia do Vale do Rio Doce, Brasil

\section{Resumo}

Este trabalho apresenta uma interpretação do desastre da Samarco/Vale/BHP Billiton centrada nas relações entre Estado, mercado e sociedade civil e na reconfiguração da regulação ambiental da indústria extrativa mineral no Brasil. Dessa forma, discute as transformações mutuamente constitutivas nos papeis do Estado e das empresas envolvidas, com ênfase nas dimensões ambiental e social, e explicita a exclusão seletiva da sociedade civil no processo. Baseando-se em análise documental e observação direta, são investigadas as formas regulatórias relacionadas ao licenciamento e ao monitoramento ambiental das operações da Samarco, assim como à gestão dos impactos do desastre no Vale do Rio Doce, com o estabelecimento da Fundação Renova. Os resultados sustentam o argumento da combinação entre padrões de regulação fraca e privada (autorregulação), integrando dimensões 'negativa' e 'positiva', que acrescem ao processo de desconstrução institucional formas empresariais de regulação privada e pública politicamente construídas.

Palavras-chave: mineração; regulação; relações Estado-mercado; desastre; Samarco. 


\section{The construction of the disaster and the "privatization" of mining regulation: reflections on the tragedy of the Rio Doce Basin, Brazil}

Bruno Milanez

Rodrigo Salles Pereira dos Santos

\section{Introduction}

In this study, we use the case of the disaster of the Rio Doce basin, caused by the failure of the Fundão Dam, controlled by Samarco Mineração S.A., on November 5, 2015, to explore possible changes in the trajectory of environmental regulation of the extractive industry in Brazil. We argue this case presents convincing data, both of the mix between public and private standards of regulation as well as of the former being replaced by the latter (Jackson and Rathert 2017), potentially driving a 'move', from a 'weak' model to one of self-regulation.

As we will discuss throughout the paper, environmental control in Brazil was based initially on a weak regulatory standard (Guimarães 1991). Despite the complexity and diversity of the environmental legislation, its implementation, seen as the weakest link of the environmental system (Hochstetler 2002), remained insufficient and did not meet expectations, both at federal and state levels. Due to historical institutional factors, mining assumed an important place in the collective imagination of Brazilian society and of bureaucrats and politicians, being symbolically linked to development and to expectations of employment and well-being (Enriquez 2007).

Along these lines, the establishment of a regime of environmental control of the extractive industry in Brazil can be identified with the notion of regulatory capture, defined as "de facto control of the state and its regulatory agencies by the 'regulated' interests" (Mattli and Woods 2009: 10). According to O'Callaghan and Vivoda (2013), this process can occur in situations where private corporations are able to accumulate sufficient power to dissolve the neutrality of regulatory entities or, at least, diminish the efficacy of this control.

From a theoretical point of view, this kind of analysis is relevant as a form of deepening the understanding of the firm-state relation (Block and Evans 2005). In this sense, it is most closely associated with critical studies on the various manifestations of neoliberal discourse about environmental regulation, particularly in the extractive sector. At the same time, the study is important from a social perspective, given that changes in environmental regulations have direct implications for social contestation, as well as the fact that its improved understanding may contribute to guide social movements' strategies in influencing the public debates concerning mining in Brazil.

In order to present this argument, we divided the paper into five sections, in addition to this introduction. Initially, we offer a brief presentation on the conceptual debate concerning private regulation of economic activity and the recent rearrangement of the relations between State, market and civil society. In the following section, we describe in a general manner several formative elements of the Brazilian environmental sector, its mode of regulation and institutional capacity. Next, the collapse of the Fundão dam is discussed in detail. We analyze how a weak regulation framework in Minas Gerais allowed for the 
licensing of a project which did not present environmental feasibility and, furthermore, how the dam monitoring system of the state has been ineffective in guaranteeing the safety of existing dams. Following this, we discuss the agreement signed between Samarco, the state governments of Minas Gerais and Espírito Santo and the Federal Government. We examine how the emergence of self-regulation practices in the sector has blended with and/or replaced public regulation devices as much as it has curtailed the chances of effective mitigation and compensation of the socio-environmental impacts of economic activities. In the final section, we go further in discussing recent proposals of changes in environmental legislation in both federal and state levels.

\section{Between State and market: metamorphoses on the social regulation of economy}

This section comprises a non-exhaustive literature review on the establishment of private and voluntary forms of regulating economic activities, particularly the extractive industry, and a broader discussion on its impacts for rearranging the relations between State, market and civil society.

Economic sociology literature has obstinately rejected the opposition between State and market as key institutions organizing the economy, viewing the latter and politics as socially overlapping, "mutually constituting spheres of activity" (Block and Evans 2005: 505). Based on the more general argument of the embeddedness of economic behavior and institutions in social relations (Granovetter 2007), conceiving economy and politics - and their basic institutions, market and State, respectively - as embedded would challenge the key claim of substantivist economic anthropology, that is, that modernity is characterized by the progressive autonomization of the economy in relation to society (Polanyi 2013).

Accordingly, facing the impossibility of economy's full autonomization, the empirically robust argument of the embeddedness has been systematically put forward by the New Economic Sociology (NES). At the same time, in light of the 'fading' of the historical-structural framework, which supported the metaphorical appeal of 'spheres' in relation, an interactionist conception of embedding social relations became prevalent.

Nevertheless, the relation between the embeddedness condition of economic life in social relations and the historical process of differentiation and institutionalization of economic phenomena in relation to politics and society seems to be one of complementarity rather than of opposition. Furthermore, the relative autonomy and dependence of both the analytical spheres of economy, politics and society and their key institutions can (and should) be interpreted from a dynamic perspective.

Indeed, not so recent changes in the forms of extra-economic influence on economic phenomena have been shifting the regulation over a diversified set of industrial activities (particularly those resource- and labor-intensive) from customary patterns of 'command and control', compulsory and applied by the State, "towards regulatory forms based on different social control strategies - like market mechanisms, the provision of information, and informal shaming processes" (Bartley 2003: 433-434). St-Laurent and Le Billon (2015: 2) sum up these mutations as "a shift from "government" to "governance" in natural resource management", replacing "government-industry negotiations" or diadic interactions by "multistakeholderism".

If the authors are correct in assuming a "repositioning [of] the state and its responsibilities" (St-Laurent and Le Billon 2015: 591), it seems equally important to remark the noteworthy changes derived from that for the broader relations between economy, politics and society, as well as for institutions such as the State and market, and for economic and non-economic actors. 
In practice, different branches of specialized literature are dealing with the multiple forms assumed by these processes of regulatory change and substitution. These include terms that are not always clearly defined and are used almost interchangeably, such as "voluntary approaches, self-regulation, selfcommitments, environmental accords, private agreements, voluntary initiatives, industry initiatives and public voluntary schemes" (Schiavi and Solomon 2007: 28). In addition, expressions like "corporate codes of conduct, sustainability reporting, eco-labeling, social auditing, independent monitoring, and Fair Trade products" (Bartley 2003: 435) are other possible forms.

In order to make sense of this diversified set of regulatory devices, broader definitions have also been proposed, such as "global private regimes, non-state market-based governance, industry self-regulation and/or corporate social responsibility (CSR)" (Dashwood 2013: 456).

These proposals have had a major influence on the academic literature in areas such as public management, public policy and strategic planning, consolidating as New Public Management, particularly in countries of the Anglo-American tradition (Porter and Brown 2013). New Public Management is, largely, based on the neoliberal endorsement of the free market and competition principles (Lorenz 2012). Some of its major claims comprise the increase of flexibility, customer-oriented servicing (rather than citizenoriented), competition among public institutions, and the establishment of a private, commercial and market-based culture (Lynn Jr. 1998).

The devices in question have been oriented to regulate from operational units (mines or factories, for example), to firms or entire corporations, and even included entire industrial sectors or goods and service markets as object of regulation.

In short, the specialized literature highlights the changes of the management forms resulting from these devices' emergence as moving towards privatization, i.e., for increasing private or hybrid forms of regulation to the detriment of the public ones (Bartley 2003, 2014; Clapp 1998; Dashwood 2013; Jackson and Raghert 2017; Marques 2016; Schiavi and Solomon 2007; St-Laurent and Le Billon 2015; Vogel, 2010). Despite its either critical or normative tones, this literature portrays such a trend as an expansive and inclusive move embracing economic and social actors (multi-stakeholderism, see Marques [2016]) as different as collective (trans)sectoral organizations and institutions, corporate foundations, NGOs, affected communities, native populations, etc.

Although private-led, such a move does not overlook the State. Accordingly, the State is acknowledged by its unique capacity "to shape market access on a large scale and institutionalize the rights of citizens and firms within their borders" (Bartley 2014: 96). In addition, it might be considered for its ability "to govern at a distance and ensure the governmentality of the mining sector by delegating some of its responsibilities" (St-Laurent and Le Billon 2015: 592).

Some authors (Dashwood 2013; Marques 2016; Vogel 2010) also emphasize a switch from mandatory compliance regimes to voluntary ones; voluntary codes of conduct, such as the ISO 14000 (Clapp 1998), being exemplary. Still others argue for the emergence of a "composite picture of a 'compulsory voluntary initiative"' (Schiavi and Solomon 2007: 38). Nevertheless, their regulatory focus remains under-theorized, being related mostly to the environment, but including other areas such as labor (Bartley 2003), human and cultural rights (Haalboom 2012) and gender (Keenan, Kemp and Ramsay 2016).

In regard to the scales of private regulation, this seems to be a debate which has remained underdeveloped. Whereas Marques (2016: 619) perceives a "shift in focus to more encompassing initiatives", such that "“"collaborative governance" and "scaling up" have become part of mainstream thinking and discourse" in the Canadian extractive mining industry and Clapp (1998) sees the development of environmental management standards as the key change in the conditions of competition under a "global market" and the formative basis of an "emergent international regime"; other authors simply understand 
regulation upscaling as a 'natural' move, since the "structure and scale of global production has challenged the existing capacities of governments to regulate the growing share of business activities that take place beyond their borders" (Vogel 2010: 73).

More importantly, the range of economic regulation devices deserves specific attention. From this perspective, codes of conduct and management standards (Clapp 1998); labels and certifications (Bartley 2003, 2014); collective guidelines, including Corporate Social Responsibility (CSR) (Bebbington 2010; Dashwood 2013; Haalboom 2012; Marques 2016); agreements (St-Laurent and Le Billon 2015); and foundations and trusts (McElroy 2012) have been remarkably relevant.

Clapp (1998) discusses the establishment of codes of conduct and management standards, as well as private standard-setting organizations. The author considers the general adherence to the ISO standard $14000^{1}$ as the formation of a hybrid regulation regime. Although "dominated by private industry interests, particularly those in industrialized countries", such a hybrid regime penetrates "into national standards, governmental regulations, and intergovernmental policies" (Clapp 1998: 304), with deleterious effects on national systems of environmental regulation. Seen as "less intrusive" regulatory devices (Clapp 1998: 300), codes and standards have become decisive in accessing external sources of capital and rearranging sectoral competition.

Similarly, Bartley (2003) discusses the emergence of labeling and certification of socio-environmental performance based on independent accreditation bodies. The author ascribes their evolution to the convergence between a social contestation movement in textile and timber industries and a "neo-liberal institutional context [which] encouraged States and NGOs to build private regulatory associations", to the detriment of "governmental and intergovernmental regulation" modes (Bartley 2003: 456-457). These private, non-profit associations, comprised of firms and NGOs, such as the Forest Stewardship Council (FSC) and the Fair Labor Association (FLA), for example, are understood in relation to a "competition between alternative sets of solutions and conflicts between actors" (Bartley 2003: 437) in "a field shaped by power, interests, and preexisting institutional arrangements" (Bartley 2003: 438).

With regard to CSR, "a range of unilateral and collaborative strategies in order to respond to the reputational crisis" (Dashwood 2013: 469-470) of the extractive industry in the 199os came on the scene. Early movers in adopting corporate social responsibility programs, such as Noranda (currently Glencore Xstrata) and Placer Dome (now Barrick Gold), may have steered collective guidelines at the level of sectoral associations, such as the International Council on Metals and Mining (ICMM). Increasingly important, these collective arrangements emerged in relation to the global expansion of major TNCs' operations and were driven at improving sectoral, socio-environmental performance.

For Bebbington (2010: 106), however, the spread of CSR programs and the increase of social conflict in the Peruvian extractive industry are correlated. The author argues these "programmes seek to delegitimize conflict as a valid means of expressing concerns and as a legitimate pathway towards institutional change", limiting public debate and the emergence of other potential routes for institutional change - including governmental and intergovernmental ones (see also Bartley 2003).

In turn, Haalboom (2012) notes that although sector-led CSR guidelines imply specific forms of corporate compliance, it is hardly likely that they satisfy expectations of improved socio-environmental performance and reinforce the defense of affected groups' rights - as the ICMM support of the nonrecognition of native populations' international rights in the Surinam on the part of the BMS (a subsidiary

1 Since Vale S. A. was the first transnational corporation (TNC) in mining to attain this standard (Enriquez and Drummond 2007) and Samarco S.A. the "first iron ore mining company in the world to receive the ISO 14001 certification for all phases of the productive process" (Dias 2015), it is important to understand these corporations as early environmental movers as a result of the changes in the regime of competition, as suggested by Clapp (1998). See Tubino, Devlin, and Yap (2011) about Vale's obtaining the ISO 14001 standard. 
of BHP Billiton) has demonstrated. In this sense, CSR should be seen as a context both enabling and restraining, being subject to power dynamics. Accordingly, as far as it may offer "a mechanism by which local communities and their transnational networks can pressure MNCs to recognize human rights, rights that the state may not be recognizing" (Haalboom 2012: 969), CSR may prompt only "superficial engagements with marginalized groups", being resistant to "any kind of fundamental change" (Haalboom 2012: 977).

The examination of the Canadian mining industry's pioneering response to its reputational crisis does not seem to be more promising. Marques (2016) analyzes the competition among three forms of regulation in the sector - State regulation, cross-sector private regulation and decentralized private regulation -, which has favored the latter. The author disputes the normative interpretations on the roles of sectoral associations and, mostly, of the State in raising mining operational standards. In this case, "rather than promoting consolidation, the [Canadian] government has implemented policies that actively encourage regulatory fragmentation (Marques 2016: 9), to the detriment of the legal prerogatives related to its "power to investigate overseas operations and guideline compliance" (Marques 2016: 7), and of the multistakeholder types of controlling the Canadian extractive industry.

St-Laurent and Le Billon (2015) analyze private agreements for compensation for the impacts and sharing of benefits associated to mining projects, and aimed at obtaining the social license to operate. Usual in multiethnic settings, impact and benefit agreements (IBAs) or community development agreements (CDAs) constitute voluntary private contracts among sponsors of extractive projects and affected communities - Aborigines in the Canadian case. By transferring responsibilities to non-State actors, this kind of private agreement would reduce conflict levels over resources as it replaces adversarial for consensual political forms, in favor of governments and firms.

However, IBAs may also be seen as a set of techniques and discourses shaping individual and collective actors' behavior. For St-Laurent and Le Billon (2015: 591), these agreements are based on the "selective absence" and distancing of the State from arbitrating market-society relations. In this sense, private agreements would allow companies "to reconcile both the pressure to ensure more ecologically and socially 'sustainable' practices in the mining sector while maintaining economic development and competitiveness" (St-Laurent and Le Billon 2015: 591). As a result, access to and control over mineral resources would be systematically supported by the decreasing "authority of the government [...] by the delegation of power to corporations" (St-Laurent and Le Billon 2015: 593).

Finally, the establishment of corporate foundation $\mathrm{s}^{2}$ in the extractive industry meets partially the "demands from activists, communities, and investors concerned with social risks, reputations, social license to operate, and improvement in the distribution of the benefits of mining operations" (McElroy 2012: 242). According to the author, "foundations are typically site-specific or region-specific" (McElroy 2012: 241), dealing directly with geographically bound impacts and beneficiaries, and mediating contestation towards the "legitimacy of direct corporate social investment programs" (McElroy 2012: 248).

In practice, the relatively independent, organizational forms of corporate social investment - of which foundations are exemplary -, develop governance structures comprised of or even led by civil society organizations. Also, they allow for the autonomous management of "finances and social investment programs separately from the management of individual mines and MNCs" (McElroy 2012: 249). According to the author, it is precisely such an "external' form of corporate foundations" and the "perceived independence of the foundations from the influence of corporate interests" (McElroy 2012: 249) which

2 The author estimates the existence of “ 41 foundations, trusts, and funds connected to mining operations in developing nations” (McElroy 2012 ). 
provide a specific form of value to mining TNCs: a type of "form-focused value" (McElroy 2012: 241) which "determines the degree to which their work with social investment programs is seen to be legitimate"

(McElroy 2012: 249).

Despite their diversity, private regulatory devices call into question State-centered, customary forms of regulating the economic activity. Accordingly, they redefine the limits among the analytical spheres of economy, politics and society. In this sense, it is key to examine their common features, which are capable of bringing about a progressive, private-driven displacement of form and content of these spheres' key institutions.

\section{General aspects of environmental capacity in Brazil and in Minas Gerais}

The concept of capacity building originated in the proposals of multilateral organizations, which argued for the development of institutional capacity by countries on the periphery dependent on international aid (Kirchhoff 2006). In this perspective, some studies proposed to examine the extent to which the matter needed to be adapted to deal with environmental issues, introducing the concept of capacity development for the environment. The concern with a specific type of institutional capacity for environmental issues is justified by Sagar (2000) based on the claim that environmental problems are multisectoral, present a high degree of complexity and uncertainty, and generate long-term impacts, the causes of which are not always clearly defined.

Thus, the concept of environmental capacity would complement the capacity building perspective, overly centered on the abilities of governmental agencies. Environmental capacity proponents argue that "a country's capacity for environmental protection is not and cannot be restricted to government policies. Increasingly it depends on societal forces of all kinds" (Jänicke 2002: 2). This idea is based on the assumptions that "material, institutional and socio-cultural capacity of a country are more relevant in determining the outcome of environmental policies than its choice of policy instruments" (Jänicke 1992: 47), and "successful environmental protection is brought about by a complex interaction of influences and not by a single, isolated factor, nor a favourite instrument, nor a single type of actor, nor a particular framework condition or institution" (Jänicke 2002: 4).

Among studies that address the question of environmental capacity in Brazil, many call attention to considerable institutional and sociocultural limitations.

At the federal level, Guimarães (1991) has already argued that environmental management was created in the realm of State technocracy, which, accordingly, turned economic growth into its primary objective. Similarly, Hochstetler (2002) listed corruption, lack of financial resources, constant restructuring of environmental agencies and low level of environmental conscience as inhibiting factors of environmental capacity in Brazil. She has also indicated the coexistence of a robust environmental regulatory system with institutions created to promote economic growth as the underlying reason for scant environmental policies. In another study, Milanez and Bührs (2009) established historical causes for the environmental sector being isolated from decision-making centers at the federal sphere.

At the subnational level, Kirchhoff (2006) attributes the limited capacity for policy execution to regional disparities, which account for the differential quantity and quality of human and physical resources, as well as the lack of integration.

With regard to the state of Minas Gerais, the bureau responsible for "environmental policy" is the Minas Gerais State Council for Environmental Policy (COPAM), whose mission is to establish guidelines, policies, regulatory and technical norms, standards and other operative measures, including the responsibility for environmental licensing. COPAM is part of the structure of the State Secretariat for the Environment 
and Sustainable Development (SEMAD). SEMAD comprises the following executive bureaus: the State Environmental Foundation (FEAM), the State Institute for Water Management (IGAM) and the State Forestry Institute (IEF). In 2006, the management of SEMAD and COPAM was decentralized through Regional Collegiate Units (URCs) which, in turn, receive technical and administrative support, from their respective Regional Superintendencies for the Environment and Sustainable Development (SUPRAMs). URCs are, like COPAM, deliberative and normative agencies, while acting regionally in environmental licensing (Rodrigues 2010).

Carneiro (2005) identified that COPAM counselors' participation is highly dependent on social, cultural and specific (procedural) forms of "capital", which legitimize an oligarchic involvement in environmental decision-making and restrict the influence of popular segments' representatives. Similarly, Milanez and Oliveira (2015) described an appropriation of environmental agencies by an elite associated with the government and the business sector.

In respect to the Samarco case, insufficient action towards control by environmental agencies can be identified. In addition, the lack of punishment and the low level of the fines imposed on the company have not served as a stimulus for changing corporate practices. Despite that, the company still has been particularly reluctant to carry out compensation.

Between 1996 and 2015 (prior to the dam collapse), Samarco had been fined approximately 18 times for environmental reasons. In 2002, for example, the company was fined for silting the Macacos creek due to erosion of internal roads, a repeated violation, for which FEAM had ordered corrective action. In 2004, the company was fined (initially on $\mathrm{R} \$ 7.4$ million, a figure later reduced to $\mathrm{R} \$ 3.7$ million) for operating the Santarém dam and a long distance conveyor belt without renewing the operating license. In 2005, the company was once again fined for the high turbidity levels of water found in its dams' spillways ( $R \$ 42.5$ thousand). On the same occasion, Samarco was fined in $\mathrm{R} \$ 21.2$ thousand for high levels of particulate emissions. In January of the same year, the company was also fined for a leaking in the Germano dam, although the fine was never issued; after five years, the period of the crime expired and the lawsuit was shelved (FEAM 2006).

Samarco deploys a recurring tactic with regard to the imposition of fines, declaring itself not guilty on legal and technical grounds in all lawsuits. Thus, the company seeks to invalidate the environmental technicians' arguments or even delegitimize the legal authority of the bureau in question to apply a specific fine. Being unsuccessful, the company tries either to reduce the amount of the fines imposed or to delay the lawsuit as much as possible, looking forward to the prescription of the violation. Accordingly, the company is able to take advantage of the slowness of the legal and public administration systems.

\section{A fragile State presence: the licensing of Fundão and dam monitoring in Minas Gerais}

\section{The licensing of the Fundão Dam}

The environmental licensing process of either potentially polluting or major impact projects may be critically defined as a procedural step aimed at obtaining licenses required in legislation. Political and economic organizations implicated in licensing hardly consider turning down projects, since they regard them as vital to economic development. In fact, firms and corporations are highly influential on the political domain and on decision-making organizations such as councils, committees, etc. Accordingly, rejecting projects is exceptional. In general, project approval goes along with conditional requirements, which assume that problems identified during the licensing process can either be prevented, mitigated or compensated for at a later date (ETTERN and FASE 2011). 
The Samarco/Vale/BHP Billiton disaster illustrates that State agencies responsible for public regulation have had very limited influence over corporate practices and technical options by mining companies in Brazil, whether due either to financial, technical and operational ineptitude, or to selective (in)action.

The Fundão dam was part of the infrastructures necessary for making Samarco's mining complex operational. The dam must be understood in relation to the increase in ore extraction during the commodities' boom (2002-2011) and post-boom (since 2012) periods. Each stage of the dam's licensing until its rupture indicates the firm's strategy facing the changes in commodity prices.

The environmental licensing process began in 2005 through the submission of the Environmental Impact Assessment and the Environmental Impact Report (EIA-RIMA). These documents have been analyzed by the Minas Gerais State Environmental Foundation (FEAM). Submission occurred at the beginning of iron ore prices upsurge and was related to the expansion of extractive activities by Samarco enabled by the $\mathrm{P}_{3} \mathrm{P}$ project. The Fundão dam was the newest of the three tailings dams in the area of Mariana. The dam project anticipated an approximate total capacity for disposing 79 million $\mathrm{m}^{3}$ of clay tailings and 32 million $\mathrm{m}^{3}$ of sandy ones (Brandt Meio Ambiente 2005).

In 2007, the preliminary and installation licenses were granted. The following year, iron ore prices reached their first peak; at the same time Samarco obtained the operating license. Consequently, the company was able to benefit from a significant expansion of scale economies. In 2011, there was a new peak in prices following the crisis of 2008. At the time, Samarco requested the renewal of the operating license, which was immediately granted, and authorized until 2013. The license was associated with new expansion projects.

In 2012 and 2013, new studies submitted to FEAM alleged the premature overload of the Fundão dam (SETE 2013). With the intent of increasing scales of extraction, Samarco submitted a new EIA in 2012. This new EIA aimed at promoting the optimal use of the Fundão dam. New environmental study and report were also submitted in 2013, now driven at heightening and unifying the Germano and the Fundão dams, giving rise to a mega dam.

The company sought to increase the area of tailings disposal by merging the neighboring dams and enlarging their lifespan, as indicated in the 2005 EIA-RIMA, although there was no analysis at that time. Both projects would allow for the extraction of larger volumes of ore. Also, they would make the process less expensive, faster and more efficient (since it would take advantage of the existing framework and the water treatment and recirculating system) than building a new dam in a nearby valley, despite being potentially more destructive. This strategic guideline, with a focus on cost reduction regardless of related risks, matches the beginning of prices dropping in the post-boom period.

Also in 2013, the company requested for the renewal of the Fundão dam's operating license, which had not been approved as far as the dam collapsed. In 2014, the preliminary and installation licenses were granted together for the company to optimize the dam. Finally, in June 2015, the licenses for the heightening and unifying of the Germano and the Fundão dams were simultaneously granted.

Therefore, we can conjecture that the interventions which were taking place at the Fundão dam at the moment of the tragedy possibly refer to either one or both projects which had a valid installation license. A corporate strategy aimed at reducing operating and investment costs, framed in the context of falling commodity prices since 2011, may have affected safety and quality of the projects.

Altogether, there were three different EIA-RIMA studies for a single dam. These were submitted to the environmental regulatory agency, and made available to society and discussed in public hearings. Thus, this type of licensing process sets up a fragmentation tactic, favoring impact underestimation and miscalculation of people affected, as it allows for the company to represent impacts and affected people separately, in relation to each project. As a result, consultation with society is likewise fragmented into 
different public hearings, and it gives rise to an excess of diffuse and patchy information, disjointed into different environmental agencies and levels of political power.

Brazilian environmental legislation requires the presentation and evaluation of location alternatives to the project as part of the EIA. The dam's EIA compared the valley of the Fundão stream with the valleys of the Natividade and Brumado streams (the latter presuming a future tailings dam), all close to the exhausted Germano mine. Among the three alternatives, the Fundão dam was the only option that would produce direct impacts and cumulative effect on the Germano (beside) and Santarém (downstream) dams. Samarco recovered water for the concentration process in the latter one.

In addition, the other two alternatives to the Fundão dam were located in different watersheds, which did not drain in cumulative convergence towards the community of Bento Rodrigues. That is, if an alternative location had been chosen at that time, the community of Bento Rodrigues would have been less threatened by a potential collapse of Samarco dams. The existence of well-preserved vegetation and archeological potential were among the factors seen as troublesome in opting for neither the Natividade nor Brumado valleys. However, the EIA considered neither the risk of cumulative impact nor the distance to Bento Rodrigues as an adverse factor against the Fundão stream (Brandt Meio Ambiente 2005).

Similarly, environmental legislation also requires that EIAs consider alternative technologies and justify their options. However, the EIA of the Fundão dam did not present any technological alternative for tailings disposal. Particularly, technological alternatives for waiving dams in tailings disposal ${ }^{3}$ were not mentioned as possible solutions, if only to be evaluated as overly expensive and unfeasible on a large scale. The study was limited to a comparison of two different dam construction methods: one conventional, based on land massif, vertical filter and draining base; and the other one using the sludge itself for damming and heightening in stages, which was ultimately chosen.

The National Council for the Environment (CONAMA) Resolution 01/86 requires the Area of Direct Influence (AID) and the Area of Indirect Influence (AII) to be specified. These areas are subject to direct and indirect impacts of the licensing project, respectively. Also, in the EIA of the Fundão dam, AID was split in the Directly Affected Area (ADA) and the Peripheral Area (AE). In defining areas affected, one should consider both actual impacts, which occur independently of mitigating and controlling measures; and also potential impacts, which can occur if mitigating and controlling procedures are not taken to prevent such impacts (as was the case of the collapse in question), or in fortuitous situations.

When analyzing the biotic and physical impacts, the ADA was restricted to the area to be occupied by the Fundão dam; the Peripheral Area was limited to the Fundão stream watershed, in addition to the Germano dam regarding only for physical impacts; and, finally, the AII was limited to the sum of the latter two, in addition to the Santarém dam and the area of vegetation contiguous to it. For the social and economic impacts, the ADA was delimited as the area of dam construction, as the AE considered the village of Bento Rodrigues as "more exposed to possible effects of water quality changes stemming [either] from the dam operation, or from the provision of labor for the building phase" (Brandt Meio Ambiente 2005: 74). Finally, the municipalities of Ouro Preto and Mariana were considered as AII, "where the socioeconomic repercussions of the dam project are noticeable".

The narrow delimitation of areas of influence stipulated by the EIA for the Fundão dam demonstrates the analysts who drafted the study did consider neither the possibility of collapse, nor the chances of large-scale tailings overflow. A single social impact was foreseen during the operating phase, i.e. the increase in job creation and regional income, seen as positive effects (Brandt Meio Ambiente 2005). The study which projected the heightening of the Fundão dam and its unification with the Germano dam

3 These comprise the disposal in exhausted caves, sludge thickening, dry stack, geotextile or vacuum filtration, among others. 
confines the areas of direct influence to the same boundaries planned in 2005 and it did not contemplate the possibility of dam collapse (SETE 2013).

Accordingly, EIAs have been inadequate to convincingly identify all potential environmental impacts of large-scale projects in general, and the ones caused by mining projects, in particular. In part, these studies tend to underrate negative impacts; this can be credited to the fact that mining companies choose and hire the consulting firms that carry out the studies, giving rise to a clear conflict of interest. This situation becomes even more critical when one takes into account the ritualization of the environmental licensing process (Bronz 2015), which is likely to reinforce structural asymmetries among actors, to limit open practices of challenging powerful actors, and to favor order maintenance, leading to the project implementation.

Environmental licensing deficiencies, misinformation, and noncompliance are present in all phases of the process (preliminary, installation, operation, and closing). Legal obligations are circumvented by the subterfuge of conditional requirements, which make the process more flexible. These measures, specified by the environmental agencies or councils, aim at compelling the company to improve studies and carry out actions for improving environmental aspects of ongoing projects. On the other hand, the use of conditional requirements allows for the speed-up of the licensing process, since it makes license granting immediate, defining new timetables for complying on new and recurring requirements. In many cases, responses to conditional requirements are merely procedural, not solving problems identified.

\section{Dams monitoring in Minas Gerais}

FEAM is the state agency in charge of publishing the Minas Gerais State Dams Survey. FEAM shares the responsibility for monitoring tailings dams with the National Department for Mining Production (DNPM), a federal agency accountable for monitoring the establishment of safety plans for tailings dams. The Survey classifies mining and industrial dam projects built for the containment of either tailings or water storage. In carrying out this inventory, FEAM takes into account essentially data provided by companies, which are occasionally supplemented by on-site audits.

Audit results define three operating conditions for the dams. There are those in which the auditor "guarantees the dams are safe in relation to the physical stability of the massif, as well as the hydraulic stability" (FEAM 2014a: 29). At the same time, there are those in which "there is no conclusion regarding feasibility" because the auditor did not have access to information needed to verify the security of the dam in question. Finally, there are those in which stability is not guaranteed, which means the auditor had access to technical data and does not guarantee that the dam is safe.

In the 2014 Dams Survey (FEAM 2014b), the three Samarco dams in Mariana (Fundão, Germano and Santarém) had their stability guaranteed by the auditor. Furthermore, nearly four months prior to the collapse, the Fundão dam had its stability guaranteed by the auditing firm VogBR, which has been hired by Samarco (Bertoni and Marques 2016). The same stable condition was ascribed to the Herculano Mining dam in 2013, which collapsed and caused three deaths in Itabirito, Minas Gerais the following year.

Accordingly, the existing dam monitoring system in Minas Gerais does not guarantee the real safety of the dams. As in the case of environmental licensing, this can be attributed to the conflict of interests related to the hiring process of the firms which carry out evaluations.

However, in the few cases in which auditing firms' technical opinions do not guarantee stability of the dams, the environmental regulatory agencies seem to be either technically and politically weak, or even not prone to interfere with dams' operations. Thus, there are tailings dams that remain without stability guarantees for repeated years. Focusing only on those dams with high potential for causing environmental 
damage, the analysis of the 2011-2015 period indicates seven dams which have been classified as unstable for two years (belonging to MMX Sudeste, Namisa/CSN and Vale); three for three years (MMX Sudeste and Vale); and one for four years (Vale) (FEAM 2012, 2013, 2014b, 2015).

These data demonstrate both the fragility of legislation, which allows for dams that repeatedly lack tested stability to remain in operation; as well as the limited capacity of the state government to guarantee that mining companies meet requirements of dam safety.

\section{Is the State absent? The establishment of the Renova Foundation}

\section{Considerations on the 'conduct adjustment' by firms and the State}

Regarding the relations among Samarco, Vale and BHP Billiton, and the State, a new event has driven institutional change from the weak regulation paradigm to a self-regulation one. In March 2016, the three mining companies, the state governments of Minas Gerais and Espírito Santo and the Federal Government signed the "Terms of Transaction and Conduct Adjustment" (TTAC). By the TTAC, these actors established the Renova Foundation, a private organization responsible for the recovery, mitigation and compensation for the socioeconomic and environmental impacts provoked by the collapse of the Fundão dam (União et al. 2016). ${ }^{4}$

In general, a Term of Conduct Adjustment (TAC) is a device designed at promoting extrajudicial alternatives to solve conflicts (Rodrigues 2004), which is set up by public agencies with an actual or eventual violator of a collective right. TACs must contain varied requirements to be fulfilled by the committed party, such as the repairing of damages to collective rights, the conduct adjustment to legal and normative obligations, and/or the compensation for damages that cannot be recovered. TAC proponents often justify the need of such a device by the urgent nature of ecological disasters, since the processing delays of the judicial system may result in aggravating the consequences of environmental damages, which makes repairing even more difficult. This explains why State agencies in charge of concluding TACs give priority to environment protection, to the detriment of establishing liability for the damage (Viégas, Pinto and Garzon 2014).

The TTAC is consistent with this perspective, by declaring "the conclusion of this [out-of-court] plea agreement stems from mere liberality of the promisee, recognizing that the adoption of emergency measures is essential" (União et al. 2016:3). However, speed and effectiveness are not naturally obtained by signing these agreements. The extent to which their objectives are achieved is dependent upon rigorous proof by public authorities and affected communities. As was discussed previously, public authorities have demonstrated neither technical nor political capacity to exercise such control. With regard to collective power, the TTAC defines a governance structure for the Renova Foundation that makes the participation of affected people formalistic.

Thus, the TTAC had design shortcomings, which indicated it would fall short of achieving the expected remediation results and compensating for the impacts of the disaster. In the following, we shall evaluate some of these failures.

In the literature regarding environmental policies, there is a consistent evaluation of agreements between private companies and governments. Despite the fact that most of it concerns agreements that

4 The TTAC was certified in May 2016, although it was halted by the Supreme Court in August (Diniz 2016). In January 2017, the Federal Prosecution Service (MPF) signed a Preliminary Adjustment Term (TAP), aimed at reviewing the TTAC (MPF 2017). However, since this TAP covered the monitoring of the Foundation's actions by private firms which were service providers hired by Vale and Samarco, it was again contested by the affected communities and social movements. 
involve different companies within the same sector, some of their elements are useful to analyze the TTAC. Mostly, these elements refer to issues related to social participation, and to monitoring and control systems.

With regard to social participation, the European Environmental Agency (EEA, 1997) claims that enforcing agreements is most effective when independent parties are involved in designing and carrying them out. Similarly, Bizer and Jülich (1999) mention the need to involve the legitimate and relevant parties both in the negotiation process and in implementing the agreements. The authors further argue for public access to monitoring data and results. Cunningham and Clinch (2004) insist that public involvement is one of the main features in defining agreements, arguing for mechanisms of participatory monitoring, which involve both the media and NGOs. Similarly, a report drafted by the OECD (2003) mentions that the involvement of NGOs increases the chances of achieving the goals proposed.

Another element frequently mentioned relates to systems of monitoring, control and disclosure of results. Generally speaking, such systems should be clear and trustworthy (EEA 1997). Furthermore, the evolution of agreement results should be disclosed periodically in a detailed manner (Bizer and Jülich 1999; Cunningham and Clinch 2004).

The literature also mentions the institutional capacity of regulatory agencies as an important factor (Cunningham and Clinch 2004). Moreover, there are criticism of agreements in which private companies assume all responsibilities, since such agreements tend to be less effective (Bizer and Jülich 1999).

Despite of the literature on these issues is copious, many of the limitations it indicates can still be identified in the TTAC. Such characteristics suggest either limited technical capacity of the TTAC designers, or weak commitment for reaching the objectives proposed.

\section{Allocating State and entrepreneurial roles and 'excluding' society}

Two parties signed the TTAC. On one side, the Brazilian federal government, together with the state governments of Minas Gerais and Espírito Santo (all of them being represented by particular institutions and legal bodies). On the other side, Samarco, Vale and BHP Billiton.

The first noteworthy feature was the absence of representatives of the affected populations, who neither had the chance of participating in the discussion of the TTAC, nor were able to influence the definition of its content (Medeiros 2016). Rodrigues (2004: 85) claims "the decision-making process in concluding the conduct adjustment agreement must be the most participatory process as possible. Therefore, participatory mechanisms ideally should be made available within the decision of the legitimate body in charge of concluding the commitment". Despite this consideration, there are no legal guarantees of social participation in the proposing of an agreement such as this one. Brazilian legislation specifies State bodies as the sole proponent, neglecting the involvement of groups directly affected by environmental damages. Thus, integrating civil society organizations (CSOs) in the process of concluding the TTAC depends on the public agencies which drafted it, either by means of including CSOs as participants; or by offering conditions for indirect participation - holding public hearings, for example (Viégas, Pinto and Garzon 2014).

Thus, the absence of affected people in the drafting of the TTAC is the result of public authorities' decision to keep them apart from the process. We evaluate the way by which the TTAC was proposed suggests that public agencies share the idea that guaranteeing and defending transindividual rights and interests is a technical issue. Accordingly, these bodies have ascribed and restricted the decision-making power to the Renova Foundation, to environmental agencies, to third-party experts, and to the State bureaucracy.

By adopting strategies and methodologies that lack participatory mechanisms, the proponents of the 
agreement either limited or blocked the participation of social actors in the decision-making process, despite recommendations found in the literature, as cited above. Furthermore, the absence of guarantees of disclosure regarding the drafting of the clauses makes any attempts to exercise control over results virtually impossible.

Also relevant is the absence of the Federal Prosecution Service (MPF) and the State Prosecution Services of Minas Gerais (MPMG) and Espírito Santo (MPES). In fact, the TTAC seems to take measures to undermine future public civil actions (ACPs) of the Prosecution. Accordingly, the agreement has established that "the parties, through settlement that will be exhaustive in relation to the EVENT and its effects, intend to put an end to this ACP [no. 0069758-61.2015.4.01.340o] and other actions, with subject matter contained in or related to this ACP, ongoing or that may be filed by any agents with standing. In addition, further on, the TTAC specified that "the PROMISEES shall make submissions in the records of the lawsuits listed in the ANNEX and other class actions that may be filed with respect to the EVENT [...], in order to cause the clauses and obligations provided in this SETTLEMENT to prevail” (União et al. 2016: 6).

Thus, governmental agencies aimed at not only "to put an end to" actions against the company, but also were prepared to make official declarations in lawsuits in order to defend the TTAC from any new claims, whether by affected populations or by the Prosecution. These definitions made explicit the position of the signatory public agencies, since they placed them alongside private actors' interests, to the detriment of diffuse and collective interests.

With respect to organizational form, in Clause 01, the TTAC has established a "foundation of private right, not for profit, in compliance with the requirements of the law, to be instituted by SAMARCO and the SHAREHOLDERS in order to prepare and perform all measures provided by ENVIRONMENTAL PROGRAMS and SOCIOECONOMIC PROGRAMS" (União et al. 2016: 10). Thus, the Renova Foundation would be responsible for all recovery, remedial and compensatory actions associated with the dam collapse.

With regard to the definition of the monitoring and control agents, the TTAC has established an Inter-Federative Committee composed of State representatives, which is responsible for overseeing the programs implemented by the Foundation. This Committee would be composed of two representatives of the Ministry of the Environment, two others from federal agencies related to socioeconomic programs, four representatives of state government agencies (two from Minas Gerais, two from Espírito Santo), two from affected municipalities of Minas Gerais and one from Espírito Santo and one representative of the Doce River Basin Committee, with ties to the public power (União et al. 2016: 84).

The monopoly of Executive Branch agencies over the Committee puts a risk for monitoring activities. As discussed previously, environmental agencies have shown to be unable to guarantee an effective assessment of achieved goals, due to their low environmental capacity.

The TTAC has also specified that "all activities developed by the FOUNDATION will be subject to independent external audit to be hired by the FOUNDATION (União et al. 2016: 15). With respect to the potential firms, the TTAC has even specified that the audit should "be carried out by consulting firm among the four (4) top business leaders in action in the country, namely: Ernest \& Young (EY); KPMG; Deloitte; or Pricewaterhouse Coopers ( $\mathrm{PwC}$ ) (União et al. 2016: 69). As discussed in the previous section, the choice of and payment of auditors by the audited firms create a situation of striking conflict of interest. Such practice has already been largely contested in the specialized literature.

For example, Bazerman, Morgan and Loewenstein (1997: 90) argue that "under current institutional arrangements, it is psychologically impossible for auditors to maintain their objectivity; cases of audit failure are inevitable, even with the most honest auditors".

In another study, Boyd (2004) analyzed the global concentration process of the auditing sector, which 
culminated with the formation of the Big Four, exactly those companies chosen by the TTAC. According to the author, as companies globalized and consolidated, consulting services assumed increasing importance in their revenues, which greatly changed the relations among them and with the hiring companies. Exemplary of these changes, a PwC Canada document states the firm "will truly be a breakaway firm when our clients think of us as a professional services firm, not an accounting firm. We want them to think of us as always being able to provide them with assistance with virtually any business or industry issue they face" (Boyd 2004: 384). Along these lines, the author suggests that third-party consulting firms are becoming increasingly partners of their hiring companies, rather than "watchdogs". To some extent, this process may reduce the degree of independence in their auditing activities and in the evaluation of their contractors.

In addition, an article published in The Economist (2014) focuses on the performance of the Big Four. It has not only brought up fraud cases in which some of these firms were involved, but also argued that "companies tend to select auditors who will provide a clean opinion as cheaply and quickly as possible". Following this reasoning, one may conclude that allowing firms to choose their auditor tends to generate conflicts of interest, which would be minimized if that choice was made in a different manner.

Finally, the TTAC has provided for the creation of an Advisory Panel of Experts, composed by three members: the first being appointed by the Renova Foundation, the second by the Inter-Federative Committee, and the third one in agreement by both parties. This Panel should "provide technical opinions that are not binding to the parties, in order to assist in the search for solutions to divergences" (União et al. 2016: 87). Specifying the non-binding character of these technical opinions already indicates the limited power of the Panel experts.

Accordingly, the TTAC has excluded both the Prosecution and the affected people from the monitoring and control actions. Generally speaking, by transferring these activities to third-party auditing firms, the TTAC has not only reproduced the environmental policy model which allowed for the collapse of the dam, but it has also deepened a pattern of environmental self-regulation, despite all the limitations inherent to its application in countries which have low institutional capacity, such as Brazil.

One of the aspects most criticized by the social movements with respect to the TTAC was related to the methodology for defining affected people. The document has not only provided the Renova Foundation with the power to arbitrate who will be treated as affected people, but it has also established a series of restrictions and requirements for people to be recognized as affected and, consequently, for being compensated.

Firstly, the TTAC has transferred the power to determine which people will (and will not) be considered as affected to the Foundation, since it has the prerogative of defining eligibility and the compensation parameters.

CLAUSE 34: The FOUNDATION shall create indemnification parameters considering the socioeconomic condition of AFFECTED [PEOPLE at] their PREVIOUS SITUATION, as well as the general principles established by Brazilian law and parameters of existing precedents on Brazilian courts.

$[\ldots]$

PARAGRAPH TWO: determination of the eligibility of IMPACTED for NEGOTIATION PROGRAM COORDINATED, as well as the general indemnification parameters to be established within the same will be proposed by the FOUNDATION and will be submitted to INTER-FEDERATIVE COMMITTEE for validation (União et al. 2016: 28).

Secondly, the TTAC has included a series of formal requirements, which would be difficult to meet by 
people whose lives were destroyed by a 'wave of mud'. In order to be officially registered as eligible, affected people would be required to present documents that prove their personal data, family income, and personal and property losses. Only in "exceptional cases" would the Foundation accept other forms of proof (União et al. 2016: 25).

Another element that characterizes the State selective absence from the process is related to monitoring. In Clause 10, the TTAC has specified that there should be "mechanisms to assure the just, simple and quick negotiation, which might be followed up by the Public Authority" (União et al. 2016: 21). Therefore, the document indicates that negotiation between the Renova Foundation and the affected people should be immediate, on an individual basis, and without any guarantees of mediation by public authorities. Given the power asymmetry between affected people and negotiators representing the Foundation, it is difficult to imagine that these discussions will fully meet the needs of the former. The current vulnerability and dependence of these people, many of whom are living in houses rented by Samarco and surviving by means of financial 'aid' paid by the company, would contribute to their relative powerlessness in individual negotiations with the Foundation.

Far from being exceptional, these examples are illustrative of the sociopolitical mechanisms of an institutional arrangement that attributes specific roles both to the private companies involved in the disaster, and to the different State organizations involved in managing its impacts, while neglecting the demands and claims of the affected people. More importantly, the TTAC and the innovative institutional 'solution' represented by the Renova Foundation points to the emergence of a pattern of environmental selfregulation in the Brazilian mining industry.

\section{Final considerations}

Throughout this paper, we have mobilized the collapse of the Fundão dam to describe some traces of a potential change in the trajectory of the environmental regulation policy in Brazil; the move from a model based on weak regulation to one of self-regulation. Thus, while environmental licensing and monitoring of tailings dams remain subject to a fragile, formal type of State control; the monitoring and auditing of recovery and environmental compensation actions resulting from the disaster have been transferred to a private foundation and to third-party consulting firms hired by the former. Such a change is not particular to Brazil, but rather is consistent with global tendencies linked to the advance and deepening of neoliberalism.

However, this transition is neither linear nor immediate. Moving from the case of the Fundão dam to changes in environmental legislation, we can identify trends driven at consolidating both models.

In 2016, Governor Fernando Pimentel (PT/MG) approved law 21972/2016, which changes the State Environmental System (SISEMA). This new act has not only limited the time for the assessment of environmental impact studies by State agencies (clause 21), but also has allowed for the licensing to be debated and approved without due analysis by the appropriate technical agencies (clause 23). In addition, the law created the category of "priority projects", the importance of which would be discretionary. These projects would not be appraised by technical agencies, but rather by a complementary structure of the State Secretariat for the Environment and Sustainable Development (clauses 5, 24 and 25). In March 2016, Senator Blairo Maggi (PP/MT) submitted to the Federal Senate the bill 654/2015 (PLS 654/2015), which has established the "special environmental licensing of strategic infrastructure projects". With a wording very similar to that of the Minas Gerais law, this bill has limited the time available for assessments by environmental 
agencies and has provided that "the non-fulfillment of deadlines by agencies which have been notified will entail their acquiescence to the process of special environmental licensing" (clause 5, paragraph three).

Accordingly, reducing the time available for assessments, as well as replacing technical analyses by ad hoc political evaluations, tend to deepen the weak regulation model.

On the other hand, the Commission of Constitution, Justice and Citizenship of the Federal Senate has approved the Proposed Constitutional Amendment 65/2012 (PEC 65/2012) in April 2016. As such, it aims at including the following article in the Federal Constitution: "The submission of prior environmental impact study implies authorization to implement the project, which may not be suspended or cancelled for the same reasons, except in view of supervening fact". If approved, this Amendment would make the assessment of environmental impact studies unnecessary since submitting a prior study would guarantee authorization. That would be a clear shift towards a self-regulation model.

However, it is noteworthy that the national environmental system has never been effectively completed. Since the establishment of the Special Secretariat for the Environment (SEMA) in the 1970s, as noted by Guimarães (1991: 192), environmental agencies have been placed "at a bus stop where the bus of power does not stop". Similarly, as Ames and Keck (1997) have noticed, Brazil has always been dominated by an ethos of natural resources' appropriation and, since the 1970s, by a permanent bias against policies driven at regulating economic growth.

Along these lines, although a presumed "continuum that ranges from "hard" law at one end, to "soft" law or CSR on the other" (Marques 2016: 2) is effectively shown as replacing weak regulation by selfregulation, it seems to be necessary to enlarge the framework.

Taking into account Boltanski and Chiapello's “interplay between three terms" (2005: 29), i.e. accumulation, critique and justification, as defining capitalism, the critical point of such a transition is no longer its result - the emergence of private and/or hybrid regulatory forms. It rather comes to reside in its movement. Accordingly, it is key to focus on the process by which organizational forms of regulation assume weak and/or private forms as dominant features. Moreover, the ongoing change in efficiency criteria towards regulation may be as important, or even more so, than specific organizational forms.

It is in these terms that St-Laurent and Le Billon (2015) reclaim Foucaldian reflections on the capacity of neoliberalism to redefine, on enduring bases, the limits of State action and of its diffuse effects on the human conduct. More broadly, we highlight the capacity of neoliberalism to continuously rearrange the relations between State, market (Block and Evans 2005) and civil society, and equally to redefine the forms and contents of social action of an economic type.

Extending this reflection, we argue that private and/or hybrid devices or mechanisms of regulation, among which the emergence of the Renova Foundation stands out, operate continuously as "technologies of government" (St-Laurent and Le Billon 2015: 592). Such mechanisms are dependent on State active participation in their formation and entrenchment - even when acting as a 'fiduciary', bestowing trust on the emerging regulatory forms.

Therefore, we go against the spread viewpoint on this set of phenomena. In spite of focusing on its negative dimension - based on a minimal State model and on the 'deconstruction' of welfare organizations and institutions - we highlight its role as technical means of influence over the conduct of individual and collective actors. Accordingly, we understand neoliberalism based on its normative properties, capable of creating new institutional arrangements, by "repositioning" (St-Laurent and Le Billon 2015: 591) the relations between economy, politics and society.

Among other State roles, those related to controlling the access to (and the behavior in) markets 
and to the institutionalization of rights (Bartley 2014) are progressively delegated and extinguished, as far as they are contractually reframed as agreements. Differently from simple inaction, the progressive 'deconstruction' of governmental regulatory forms of the market-society relations - and the systematic opposition to intergovernmental arrangements - give rise to selective patterns of State, market and civil action and omission. Such forms allow for a more diffuse and asymmetric exercise of power, and the emergence of a 'soft', permanent regulation of the mining industry, aimed at anticipating and sidetracking any risks associated with its continuous expansion.

As a result, the technologies of government under discussion are mainly driven towards private forms of controlling the economic activity, propelling a dynamic process of privatization of regulation - as well as the autonomization of the economic sphere and their actors, in the Polanyian sense. Nevertheless, these technologies are dependent on decentralized dynamics of power and on the engagement of diverse actors to fulfill "the potential to maintain and (re)produce the state's historical role as an ally" of economic actors, as well as "of the mining industry in developing the sector" (St-Laurent and Le Billon 2015: 591). As such, technologies of government are socially and politically constructed, reconciling both the perspectives of autonomization and embeddedness of all economic activity in social relations.

Translated by Franklin Rothman

Revised by Rodrigo Salles Pereira dos Santos e Bruno Milanez

Received at March 18, 2017; Accepted at April 02, 2017

* The authors thank the Fundação de Amparo à Pesquisa do Estado de Minas Gerais (FAPEMIG), the Fundação de Amparo à Pesquisa do Estado do Rio de Janeiro (FAPERJ), and the Conselho Nacional de Desenvolvimento Científico e Tecnológico (CNPq) for the financial support that enabled us to carry out research and write this paper.

\section{References}

AMES, Barry; KECK, Margaret E. 1997. "The politics of sustainable development: environmental policy making in four Brazilian states." Journal of Interamerican Studies and World Affairs, 39(4): 1-40.

BARTLEY, Tim. 2003. "Certifying forests and factories: states, social movements, and the rise of private regulation in the apparel and forest products fields." Politics \& Society, 31(3): 433-464.

. 2014. “Transnational governance and the re-centered state: sustainability or legality?" Regulation \& Governance, 8(1): 93-109.

BAZERMAN, Max H.; MORGAN, Kimberly P.; LOEWENSTEIN, George F. 1997. "The impossibility of auditor independence." Sloan Management Review, 38(4): 89-94.

BEBBINGTON, Anthony. 2010. "Extractive industries and stunted states: conflict, responsibility and institutional change in the Andes." In: R. Raman and R. D. Lipschutz (orgs.), Corporate social responsibility: comparative critique. London: Palgrave MacMillan. pp. 97-116.

BERTONI, Estevão; MARQUES, José. 2016. “Qualquer engenheiro faria cálculos que fiz em Mariana 
(MG), diz indiciado." Last Modified 17 Mar. Accessed o1 Mar 2017. http:/|www1.folha.uol.com.br| cotidiano/2016/03/1751384-qualquer-engenheirofaria-calculos-que-fz-em-mariana-mg-diz-indiciado. shtml.

BIZER, Kilian; JÜLICH, Ralf. 1999. "Voluntary agreements - trick or treat?” European Environment, 9: 59-66. BLOCK, Fred; EVANS, Peter. 2005. "The State and the economy.” In: N. J. Smelser and R. Swedberg (orgs.), The handbook of economic sociology. 2a ed. Princeton, Oxford: Princeton University Press. pp. 505-526. BOLTANSKI, Luc; CHIAPELLO, Ève. 2005. The new spirit of capitalism. London, New York: Verso.

BOYD, Colin. 2004. "The structural origins of conflicts of interest in the accounting profession". Business Ethics Quarterly, 14: 377-398.

BRANDT MEIO AMBIENTE. 2005. Estudo de Impacto Ambiental - EIA. Barragem de Rejeito do Fundão. Nova Lima. Mimeo.

BRONZ, Deborah. 2015. Nos bastidores do licenciamento ambiental: uma etnografia das práticas empresariais em grandes empreendimentos no Brasil. Rio de Janeiro: Contra Capa.

CARNEIRO, Eder Jurandir. 2005. "A oligarquização da política ambiental mineira.” In: A. Zhouri, K. Laschefski and D. B. Pereira (orgs.), A insustentável leveza da política ambiental: desenvolvimento e conflitos ambientais. Belo Horizonte: Autêntica. pp. 65-88.

CLAPP, Jennifer. 1998. "The privatization of global environmental governance: ISO 14000 and the developing world." Global Governance, 4(3): 295-316.

CUNNINGHAM, James A.; CLINCH, J. Peter. 2004. "An organizing framework for the implementation of environmental voluntary approaches". European Environment, 14: 30-39.

DASHWOOD, Hevina S. 2013. "Global private governance: explaining initiatives in the global mining sector.” In: J. Mikler (org.), The handbook of global companies. Oxford: John Wiley \& Sons Ltd. pp. 456-473.

DIAS, Luiz Guilherme. 2015. “O que falta para assegurar a sustentabilidade?” Relações com Investidores, 199: 24-25.

DINIZ, Maiana. 2016. “Justiça anula homologação de acordo entre Samarco, Vale, BHP e União.” Last Modified 18 Aug. Accessed o1 Mar 2017. http://agenciabrasil.ebc.com.br/geral/noticia/2016-o8/justicaanula-acordo-entre-samarco-vale-bhp-e-uniao-e-mantem-acao.

EEA. 1997. Environmental agreements, environmental effectiveness. Vol. 1, Environmental Issues Series. Copenhagen: European Environmental Agency.

ENRIQUEZ, Maria Amélia Rodrigues Silva. 2007. Maldição ou dádiva? Os dilemas do desenvolvimento sustentável a partir de uma base mineira. Ph.D. Thesis, Serviço Geológico do Paraná, Centro de Desenvolvimento Sustentável, Universidade de Brasília. Brasília.

.; DRUMMOND, José. 2007. "Social-environmental certification: sustainable development and competitiveness in the mineral industry of the Brazilian Amazon". Natural Resources Forum, 31(1): 71-86.

ETTERN; FASE. 2011. Projeto Avaliação de Equidade Ambiental como instrumento de democratização dos procedimentos de avaliação de impacto de projetos de desenvolvimento. Relatório Síntese. Rio de Janeiro. Mimeo.

FEAM. 2006. Parecer Técnico DIMIM n. 062/2006. Samarco Mineração S.A. Mina de Alegria e Germano. edited by F. F. E. d. M. Ambiente. Mimeo. . 2012. "Lista de Barragens 2012." Accessed o1 Mar 2017. http://www.feam.br/images/stories/arquivos/ Gestao_Barragens_2006/2012/lista_das_barragens_2012.xls. . 2013. "Lista de Barragens 2013." Accessed o1 Mar 2017. http://www.feam.br/images/stories/ inventario/2013/lista\%20de\%2obarragens\%20-2013.xls. 2014a. Inventário de barragem do estado de Minas Gerais - ano 2014. Belo Horizonte: Fundação Estadual 
do Meio Ambiente.

. 2014b. "Lista de Barragens 2014." Accessed o1 Mar 2017. http://www.feam.br/images/stories/2015/

DECLARACOES_AMBIENTAIS/GESTAO_DE_BARRAGENS/lista\%2ode\%2obarragens_2014_publicao.xls. . 2015. “Lista de Barragens 2015." Accessed o1 Mar 2017. http:/|www.feam.br/images/stories/2016|

BARRAGENS/Lista_de_Barragens_Divulga\% $\mathrm{C}_{3} \% \mathrm{~A} 7 \% \mathrm{C}_{3} \% \mathrm{~A}_{30}$ _Vo2.xlsx.

GRANOVETTER, Mark. 2007. "Ação econômica e estrutura social: o problema da imersão." RAE eletrônica, 6(1).

GUIMARÃES, Roberto P. 1991. The ecopolitics of development in the Third World: politics and environment in Brazil. Boulder, London: Lynne Rienner Publishers.

HAALBOOM, Bethany. 2012. "The intersection of corporate social responsibility guidelines and indigenous rights: examining neoliberal governance of a proposed mining project in Suriname". Geoforum, 43(5): 969-979.

HOCHSTETLER, Kathryn. 2002. “Brazil.” In: (org.), Capacity building in national environmental policy: $a$ comparative study of 17 countries. Berlin: Springer. pp. 69-95.

JACKSON, Gregory; RATHERT, Nikolas. 2017. "Private governance as regulatory substitute or complement? A comparative institutional approach to CSR adoption by multinational corporations." In: C.

Dorrenbacher and M. Geppert (orgs.), Multinational corporations and organization theory: post millennium perspectives. Bingley: Emerald Publishing Limited. pp. 445-478.

JÄNICKE, Martin. 1992. “Conditions for environmental policy success: an international comparison.” The Environmentalist, 12(1): 47-58.

. 2002. "The political system's capacity for environmental policy: the framework for comparison." In: . (org.), Capacity building in national environmental policy: a comparative study of 17 countries. Berlin: Springer. pp. 1-18.

KEENAN, J. C.; KEMP, D. L.; RAMSAY, R. B. 2016. "Company-community agreements, gender and development.” Journal of Business Ethics, 135(4): 607-615.

KIRCHHOFF, Denis. 2006. "Capacity building for EIA in Brazil: Preliminary considerations and problems to be overcome." Journal of Environmental Assessment Policy and Management, 8(1): 1-18.

LORENZ, Chris. 2012. "If you're so smart, why are you under surveillance? Universities, neoliberalism, and New Public Management.» Critical Inquiry, 38(3): 599-629.

LYNN JR., Laurence E. 1998. "A critical analysis of the New Public Management.” International Public Management Journal, 1(1): 107-123.

MANSUR, Maíra Sertã; WANDERLEY, Luiz Jardim; MILANEZ, Bruno; SANTOS, Rodrigo Salles Pereira dos; GIFFONI PINTO, Raquel; GONÇALVES, Ricardo Junior de Assis Fernandes COELHO, Tádzio Peters. 2016. "Antes fosse mais leve a carga: introdução aos argumentos e recomendações referentes ao desastre da Samarco/Vale/BHP Billiton." In: M. Zonta and C. Trocate (orgs.), Antes fosse mais leve a carga: reflexões sobre o desastre da Samarco/Vale/BHP Billiton. Marabá: Editorial Iguana. pp. 17-49.

MARQUES, José Carlos. 2016. "Private regulatory fragmentation as public policy: governing Canada's mining industry". Journal of Business Ethics, 135(4): 617-630.

MATTLI, Walter; WOODS, Ngaire. 2009. "In whose benefit? Explaining regulatory change in global politics". In: W. Mattli and N. Woods (orgs.), The politics of global regulation. Princeton, Oxford: Princeton University Press. pp. 1-43.

MCELROY, Caitlin A. 2012. "Corporate foundations in the mining industry: the relationship between responsible investment and social investment." Journal of Sustainable Finance \& Investment, 2(3-4): 240256.

MEDEIROS, Etore. 2016. “Longe das vítimas, governo assina acordo sobre desastre de Mariana. Agência 
Pública.” Last Modified o3 Mar. Accessed o1 Mar 2017. http://apublica.org/2016/o3/longe-das-vitimasgoverno-assina-acordo-sobredesastre-de-mariana/.

MILANEZ, Bruno; BÜHRS, Ton. 2009. "Extended producer responsibility in Brazil: the case of tyre waste." Journal of Cleaner Production, 17(6): 608-615.

.; OLIVEIRA, Clarissa Reis. 2015. "Capacidade ambiental no nível subnacional: o caso do estado de Minas Gerais, Brasil”. Planejamento e Políticas Públicas, 44: 317-342.

MPF. 2017. "MPF firma acordo preliminar com Samarco, Vale e BHP Billiton no valor de R $\$ 2,2$ bilhões."

Accessed o1 Mar 2017. http://www.mpf.mp.br/mg/sala-de-imprensa/noticias-mg/mpf-firma-acordopreliminar-com-samarco-vale-e-bhp-billiton-no-valor-de-r-2-2-bilhoes.

O'CALLAGHAN, Terry; VIVODA, Vlado. 2013. "How global companies make national regulation." In: J. Mikler (org.), The handbook of global companies. West Sussex: John Wiley \& Sons. pp. 155-169.

OECD. 2003. Voluntary approaches for environmental policy: effectiveness, efficiency and usage in policy mixes.

Paris: Organisation for Economic Co-operation and Development.

POLANYI, Karl. 2013. A grande transformação: as origens da nossa época. 2a. ed. Rio de Janeiro: Elsevier Brasil.

PORTER, Tony; BROWN, Sherri. 2013. "Why, when and how companies get organized.” In: J. Mikler (org.),

The handbook of global companies. West Sussex: John Wiley \& Sons. pp. 96-112.

RODRIGUES, Geisa Assis. 2004. "Princípios da celebração do compromisso de ajustamento de conduta em matéria ambiental." RevCEDOUA, 7(13): 67-88.

RODRIGUES, Gelze Serrat Souza Campos. 2010. "A análise interdisciplinar de processos de licenciamento ambiental no estado de Minas Gerais: conflitos entre velhos e novos paradigmas." Sociedade \& Natureza, 22(2): $267-282$.

SAGAR, A. D. 2000. "Capacity development for the environment: a view for the South, a view for the North". Annu. Rev. Energy Environ, 25: 377-439.

SCHIAVI, Petrina; SOLOMON, Fiona. 2007. "Voluntary initiatives in the mining industry: do they work?" Greener Management International, 53: 27-41.

SETE. 2013. Estudo de Impacto Ambiental (EIA). Unificação e Alteamento das Barragens de Rejeito de Germano e Fundão: Complexo Minerador Germano-Alegria Mariana/MG. Belo Horizonte: SETE Soluções e Tecnologia Ambiental.

ST-LAURENT, Guillaume Peterson; LE BILLON, Philippe. 2015. "Staking claims and shaking hands: Impact and benefit agreements as a technology of government in the mining sector." The Extractive Industries and Society, 2(3): 590-602.

THE ECONOMIST. 2014. “The dozy watchdogs.” Last Modified 13 Dez. Accessed 24 Mar 2016. http://www. economist.com/news/briefing/21635978-some-13-years-after-enron-auditors-still-cant-stop-managerscooking-books-time-some.

TUBINO, Denise Isabel Salomon; DEVLIN, John F.; YAP, Nonita. 2011. "A busca pela responsabilidade socioambiental em Itabira (MG).” In: F. R. C. Fernandes; M. A. R. S. Enríquez and R. C. J. Alamino (orgs.), Recursos minerais \& sustentabilidade territorial. Vol. I Grandes minas. Rio de Janeiro: Centro de Tecnologia Mineral. pp. 307-332.

UNIÃO. 2016. Instituto Brasileiro de Meio Ambiente e dos Recursos Naturais Renováveis, Instituto Chico Mendes de Conservação da Biodiversidade, Agência Nacional de Águas, Departamento Nacional de Produção Mineral, Fundação Nacional do Índio, Estado de Minas Gerais, Instituto Estadual de Florestas, Instituto Mineiro de Gestão de Águas, Fundação Estadual de Meio Ambiente, Estado do Espírito Santo, Instituto Estadual de Meio Ambiente e Recursos Hídricos, Instituto de Defesa Agopecuária e Florestal 
do Espírito Santo, Agência Estadual de Recursos Hídricos, Samarco Mineracão S.A., Vale S.A., and BHP Billiton Brasil LTDA. Terms of transaction and conduct adjustment. Brasilia. Mimeo.

VIÉGAS, Rodrigo Nuñez; PINTO, Raquel Giffoni; GARZON, Luis Fernando Novoa. 2014. Negociação e acordo ambiental: o termo de ajustamento de conduta (TAC) como forma de tratamento de conflitos ambientais. Rio de Janeiro: Fundação Heinrich Böll.

VOGEL, David. 2010. “The private regulation of global corporate conduct achievements and limitations." Business \& Society, 49(1): 68-87.

Rodrigo Salles Pereira dos Santos

Professor, Department of Sociology, Graduate Program in Sociology and Anthropology, Institute of Philosophy and Social Sciences, Federal University of Rio de Janeiro, RJ, Brazil.

E-mail: santosrodrigosp@googlemail.com

\section{Bruno Milanez}

Professor, Department of Industrial and Mechanical Engineering, Graduate Program in Geography, College of Engineering, Federal University of Juiz de Fora, Juiz de Fora, MG, Brazil.

E-mail: bruno.milanez@ufjf.edu.br 